\title{
Mite Fauna Inhabiting Animal Manures at Ismailia Governorate, Egypt
}

\author{
El-Sharabasy, H. M.; M. K. Bohibeh; A. F. El-Bahrawy and G. A. El-Kady \\ Plant Protection Department, Faculty of Agriculture, Suez Canal University, Ismailia, Egypt.
}

Received: $29 / 12 / 2015$

\begin{abstract}
Survey as well as population density of mite's fauna inhabiting organic manures in different animal sheds i.e. buffalo, cow, sheep and goats was conducted during the period from March 2013 to February 2015 in the Experimental Farm, Faculty of Agriculture, Suez Canal University. Results indicated that thirty-three species belonging to twentyeight genera and twenty-one families within 2 orders were recorded and identified. Order Acariformes was represented by suborder Actinedida (6 families and 12 species); suborder Acaridida (3 families and 3 species) and suborder Oribatida ( 2 families and 2 species). Order Parasitiformes was represented only by suborder Gamasida (10 families and 16 species). Furthemore, six families ( 9 species) were recorded in buffalo sheds; 13 families (18 species) in cow sheds; 20 families (27 species) in sheep sheds and 8 families (9 species) in goat sheds. Data also revealed that Tyrophagus putrescentiae Schrank was recorded in highest numbers, while Macrocheleus merdarus (Berlese) was relatively rare.
\end{abstract}

Keywords: Mites, Survey, animal sheds, organic manures

\section{INTRODUCTION}

Organic manures improve soil phase and play an important role in humification and provide plants with important minerals. This manure is favorite habitats for harmful and beneficial arthropods of which mites constitute the major part. Organic manures are a heterogeneous substrate, with numerous microhabitats available to the arthropods (Lindquist et al., 2009; Arjomandi et al., 2013). Mites were classified according to different feeding habitats, some of them were predators, parasites and others were free living. Surveyed mites inhabiting organic manures were studied by Mohamed (1975) in Giza region. Sherref et al. (1980) recorded mites from different organic manures, which collected from various regions of Egypt. Zaher et al. (1980) studied the population density of mites in three types of organic manures. Accumulated knowledge of the mite fauna and their density inhabiting organic manures of domestic animals is extremely poor as compared with other habitats. So the main objective of this work was a survey of mite fauna inhabiting organic manures at four animal sheds of buffalo, cow, sheep and goats in the farm of Faculty of Agriculture, Suez Canal University, at Ismailia Governorate.

\section{MATERIALS AND METHODS}

The present study was carried out from March 2013 to February 2015 in the Experimental Farm of Faculty of Agriculture, Suez Canal University, Ismailia Governorate. Samples were collected twice monthly from animal manures sheds of buffalo, cow, sheep and goats. Samples were taken from surface layer of different studied sheds, each samples was about 500 gm. Samples placed in plastic bags and transferred to the laboratory of Acarology of Department of plant protection, Faculty of Agriculture. Mites were extracted by using Tullgren funnels for at least $48 \mathrm{~h}$. and collected in beakers containing $70 \%$ ethanol alcohol, examined under stereomicroscope and counted. Collected mites kept in Nesbit's solution for few hours for clearing then mounted in Hoyer's medium. Mites were counted and identified by using keys of Krantz (1978) and Zaher (1986). According to the total individual mite families and species, the order of dominance was divided into four categories; high dominant $(++++)>100$, dominant $(+++)>50<100$, influent $(++)>25<50$ and recedent $(+)<25$, (Cusack et al., 1975).

\section{RESULTS AND DISCUSSION}

Thirty-three mite species belonging to Twentyeight genera and twenty-one families were found. These collected mites were: Order Acariformes which was represented by suborder Actinedida 6 families (12 species); suborder Acaridida 3 families (3 species) and suborder Oribatida 2 families (2 species) (Table 1).

\section{Suborder Actinedida}

Family Bdellidae Dugas was represented by 2 species, these were, Cyta laterostris (Hermann) which was found in few numbers in sheep manures, and Spinibdella bifurcate Atyeo which was found in rare numbers in sheep and goat manures.

Family Cheyletidae Leach was represented by 4 species, these were, Cheyletus malaccensis Oudemans which was found in moderate numbers in buffalo, cow and sheep manures; Cheyletus badryi Zaher\&Hassan which was found in few numbers in buffalo and cow manures; Cheyletus eruditus (Schrank) which was found in rare numbers in buffalo manures and Hemicheyletia bakeri (Ehara) which was found in rare numbers in buffalo and cow manures. Our results are in agreement with Zaher (1986) who recorded Cheyletus malacensis in organic manures in Giza region, and mentioned that this mite feed on acarid mite, Rhizoglyphus robini, collembola, eggs and larvae of housefly.

Family Cunaxidae Thor was represented by one Species, Neocunaxoides sp. which was found in rare numbers in sheep and goat manures.

Family Pygmephoridae Cross was represented by one Species, Pygmephorus sp. which was found in few numbers in buffalo, cow, sheep manures and in rare numbers in goat manures. 
Table (1): List of mite species collected from different organic manure heaps in animal sheds at Ismailia Governorate.

\begin{tabular}{|c|c|c|c|}
\hline Sub order & Family & Species & $\begin{array}{l}\text { Types of organic } \\
\text { manure heaps }\end{array}$ \\
\hline \multicolumn{4}{|c|}{ Order: Acariformes } \\
\hline \multirow[t]{10}{*}{ Actinedida } & Bdellidae & Cyta laterostris (Herman) & Sheep $^{++}$ \\
\hline & \multirow{4}{*}{ Cheyletidae } & Spinibdella bifurcate Atyeo & Sheep $^{+}$, Goats $^{+}$ \\
\hline & & Cheyletus malaccensis Oudemans & $\begin{array}{l}\text { Buffalo }_{\text {Sheep }^{+++}}^{++}, \text {Cow }^{+++} \\
\text {, }\end{array}$ \\
\hline & & $\begin{array}{l}\text { Cheyletus badryi Zaher \& Hassan } \\
\text { Cheyletus eruditus (Schrank) }\end{array}$ & $\begin{array}{l}\text { Buffalo }^{++}, \mathrm{Cow}^{++} \\
\text {Buffalo }^{+}\end{array}$ \\
\hline & & Hemicheyletia bakeri (Ehara) & Buffalo $^{+}$, Cow $^{+}$ \\
\hline & Cunaxidae & Neocunaxoides sp. & Sheep $^{+}$, Goats $^{+}$ \\
\hline & Pygmephoridae & Pygmephorus sp. & $\begin{array}{l}\text { Buffalo }^{++}, \text {Cow }^{++} \\
\text {Sheep }^{++}, \text {Goats }^{+}\end{array}$ \\
\hline & Raphignathidae & Raphignathus bakeri Zaher\&Gomaa & Sheep \\
\hline & Stigmaeidae & $\begin{array}{l}\text { Stigmaeus sp. } \\
\text { Apostigmaeus sp. }\end{array}$ & $\begin{array}{l}\text { Sheep }^{+} \\
\text {Cow }^{+}\end{array}$ \\
\hline & & Stigmaeus africanus Gomaa\&Soliman & Sheep $^{+}$ \\
\hline \multirow[t]{3}{*}{ Acaridida } & Acaridae & Tyrophagus putrescentiae Schrank & $\begin{array}{l}\text { Buffalo }^{++++}, \text {Cow }^{++++} \\
\text {Sheep }^{+++}, \text {Goats }^{++++}\end{array}$ \\
\hline & Glycyphagidae & Glycyphagus domesticus (Degeer) & Cow $^{++}$, Sheep $^{++}$ \\
\hline & Pyroglyphidae & Dermatophagoides sp. & $\mathrm{Cow}^{+}$, Sheep $^{+}$ \\
\hline \multirow[t]{2}{*}{ Oribatida } & Oppiidae & Oppia sticta Popp & Sheep $^{+}$, Goats $^{+}$ \\
\hline & Oribatulidae & Zygoribatula sp. & Sheep $^{+}$, Goats $^{+}$ \\
\hline \multicolumn{4}{|c|}{ Order: Parasitiformes } \\
\hline \multirow[t]{14}{*}{ Gamasida } & Ameroseiidae & Kleemannia plumosus (Oudemans) & $\mathrm{Cow}^{+}$, Sheep $^{+}$ \\
\hline & \multirow[t]{3}{*}{ Ascidae } & Protogamasellus denticus Naser & Buffalo $^{+}$, Cow $^{+}$, Sheep $^{+}$ \\
\hline & & Lasioseius aegyptiacus Afifi & Cow $^{++}$, Sheep $^{++}$ \\
\hline & & Blattisocius dentriticus (Berlese) & Sheep $^{++}$ \\
\hline & Digamasellidae & Dendrolaelaps zheri Metwally\&Mersal & Sheep $^{+}$ \\
\hline & Laelapidae & Androlaelaps casalis (Berlese) & Sheep $^{+}$ \\
\hline & Phytoseiidae & $\begin{array}{l}\text { Hypoaspis baloghi Shreef \& Afifi } \\
\text { Laelaspis stronemicus (Koch) } \\
\text { Typhlodromus zaheri Denmark }\end{array}$ & $\begin{array}{l}\text { Cow }^{++++}, \text {Sheep }^{++++} \\
\text {Cow }, \text { Sheep } \\
\text { Cow }^{++}, \text {Sheep }^{++}\end{array}$ \\
\hline & Uropodidae & Uropovella sp. & Buffalo $^{++}$ \\
\hline & \multirow[t]{3}{*}{ Macrochelidae } & Macrocheleus merdarus (Berlese) & $\begin{array}{l}\text { Buffalo }{ }^{+}, \mathrm{Cow}^{+}, \text {Sheep }^{+} \text {, } \\
\text { Goats }^{+}\end{array}$ \\
\hline & & M. muscadomesticae Scopoli & $\begin{array}{l}\text { Cow } \\
\text { Goats }^{++}\end{array}$ \\
\hline & & M. glaber Muller & Goat $^{++}$, sheep $^{+++}$ \\
\hline & Ologamasidae & Gamasiphis sp. & Cow $^{+}$, Sheep $^{+}$ \\
\hline & Parasitidae & Parasitus badrii Hafez and Nasr & $\begin{array}{l}\text { Cow } \\
\text { Goats }^{++++}, \text {Sheep }^{++++}\end{array}$ \\
\hline & Rhodacaridae & Rhodacarus roseus Oudemans & Sheep $^{++}$ \\
\hline
\end{tabular}


Family Raphignathidae kramer was represented by one Species, Raphignathus bakeri Zaher \& Gomaa which was found in few numbers in sheep manures.

Family Stigmaeidae Oudemans was represented by 3 species, these were, Stigmaeus sp. which was found in rare numbers in sheep manures; Apostigmaeus sp., which was found in rare numbers in cow manures and Stigmaeus africanus Gomaa \& Soliman which was found in rare numbers in sheep manures. El-Sharabasy (2010a) found Stigmaeus zaheri Gomaa and Hassan in organic manures as a predator associated with small arthropods.

\section{Suborder Acaridida}

Family Acaridae Ewing \& Nesbitt was represented by one Species, Tyrophagus putrescentiae Schrank, which was found in high numbers in buffalo, cow, sheep and goat manures. Members of family Acaridae are widely distributed and free-living, some of them are associated with insects or found in nests of small animals and living on all kinds of organic substrates (Mahgoob, et al., 2006).

Family Glycyphagidae Berlese was represented by one Species, Glycyphagus domesticus (Degeer), which was found in few numbers in cow and sheep manures.

Family Pyroglyphidae Cunliffe was represented by one Species, Dermatophagoides sp., which was found in few numbers in cow manure and rare in sheep manures.

\section{Suborder Oribatida}

Family Oppiidae Grandjean was represented by one Species, Oppia sticta Popp, which was found in rare numbers in sheep and goat manures. Lindquist et al. (2009) collected $O$. sticta with very relatively low frequency in buffalo manure and they mentioned that this species may feed on spores of fungi.

Family Oribatulidae Thor was represented by one Species, Zygoribatula sp., which was found in rare numbers in sheep and goat manures.

Order Parasitiformes was represented by suborder Gamasida with 10 families (16 species) (Table 1). These families are:

Family Ameroseiidae Evans was represented by one Species, Kleemannia plumosus (Oudemans), which was found in rare numbers in cow and sheep manures. Members of family Ameroseiidae feed on spores of fungi and hyphal fragments. This finding is in agreement with that found by Zaher (1986) who mentioned that $K$. plumosus was successfully reared on some soil fungi such as Fusarium solani.

Family Ascidae Voigts \& Oudemans was represented by 3 species, these were, Blattisocius dentriticus (Berlese) which was found in rare number in sheep manures. Lasioseius aegyptiacus Afifi also was found in few numbers in cow and sheep manures, whereas Protogamasellus sp. was found in rare numbers in buffalo, cow and sheep manures. El-Sharabasy (2010b) recorded Protogamasellus denticus Nasr in organic manures in animal sheds at Ismailia governorate.

Family Digamasellidae Evans was represented by one Species, Dendrolaelaps zheri Metwally \& Mersal, which was found in rare numbers in sheep manures.

Family Laelapidae Berlese was represented by 3 species, these were, Androlaelaps casalis (Berlese) which was found in rare number in sheep manures; Hypoaspis baloghi Shreef \& Afifi, which was found in high numbers in cow and sheep manures and Laelaspis stronemicus (Koch), which was found in few numbers in cow and sheep manures.

Family Phytoseiidae Berlese was represented by one Species, Typhlodromus zaheri Zaher \& El-Badry which, was found in few numbers in cow and sheep manures.

Family Uropodidae was represented by one Species, Uropovella sp., which was found in few numbers in buffalo manures.

Family Macrochelidae Vitzthum was represented by 3 species, these were, Macrocheleus merdarus (Berlese) which was found in rare number in sheep, buffalo, cow and goat manures; M. muscadomesticae Scopoli which was found in high numbers in cow, sheep, and goat manures and $M$. glaber Muller which was found in few numbers in sheep and goat manures. $M$. muscadomesticae was presented in all of the samples examined except buffalo manure, and this is an agreement with Kazemi and Rajaei (2013).

Family Ologamasidae Ryke was represented by one Species, Gamasiphis sp., which was found in rare numbers in cow and sheep manures.

Family Parasitidae Oudemans was represented by one Species, Parasitus badrii Hafez and Nasr, which was found in high numbers in cow, sheep and goat manures.

Family Rhodacaridae Oudemans was represented by one Species, Rhodacarus roseus Oudemans, which was found in few numbers in sheep manures.

Data showed that diversity of mite community within buffalo manures is low. This could be attributed mainly to the high moisture content. Augustin and Rahman (2010) revealed that humidity in different manure types might affect mite diversity.

A total of 12598 mite individuals were extracted during the two successive years. Mites extracted from manure of sheep recorded the highest collected $(38.38 \%$ from total collected mites). On other hand, manure from goats recorded the lowest number of collected mites $(21.16 \%)$ (Table 2).

Also results showed that there 9 species belonging to 6 families were recorded from buffalo manures. On the other hand, 18 species belonging to 13 families; 10 species belonging to 8 families and 27 species belonging 20 families were recorded from cow, goats and sheep manures; respectively (Table 1). 
Table (2): Total number of mites extracted from different manure heaps from March 2013 to February 2015 at Ismailia Governorate

\begin{tabular}{lcccccc}
\hline \multirow{2}{*}{$\begin{array}{l}\text { Manure } \\
\text { types }\end{array}$} & $\mathbf{2 0 1 3}$ & \multicolumn{2}{c}{$\mathbf{2 0 1 4}$} & Total & \% \\
\cline { 2 - 6 } & No & \% & No & \% & & \\
\hline Buffalo & 1126 & 21.41 & 1353 & 18.43 & 2479 & 19.67 \\
Cow & 2047 & 38.92 & 1638 & 22.31 & 3685 & 29.25 \\
Sheep & 1297 & 26.66 & 3539 & 48.22 & 4836 & 38.38 \\
Goats & 789 & 15.00 & 809 & 11.02 & 1589 & 12.61 \\
Total & 5259 & & 7339 & & 12598 & \\
\hline
\end{tabular}

\section{REFERENCES}

Arjomandi, E., S. Kazemi and A. Afshari (2013). Fauna and diversity of the manure-inhabiting Mesostigmata (Acari) in Kerman County, South Estern Iran. Persian Journal of Acarology, 2(2): 253-263.

Augustin, C. H. and S. H. Rahman (2010). Composting animal manures: a guide to the process and management of animal manure compost. North Dakota State University Fargo, North Dakota, 701: 1-8.

Cusack, P. D., G. O. Evans and P. A. Brennan (1975). A survey of the mites of stored grain and grain products in the Republic of Ireland. In Scientific Proceedings of the Royal Dublin Society, 3(20): 273-329.

El-Sharabasy (2010a). Actinedid mites (Acari:Acariformes: Actinedida) inhabiting soil and litter in Ismailia, Egypt, including new records. J. Egypt. Ger. Soc. Zool., 60: 65-72.

El-Sharabasy, H. M. (2010b). Abundance and diversity of soil mites (Acari: Gamasida: Oribatida) in mango orchards in Ismailia region, Egypt. Acarines: J. of the Egyptian Society of Acarology. 4: 31-36.

Kazemi, S. H. and A. Rajaei (2013). An annotated checklist of Iranian Mesostigmata (Acari), excluding the family Phytoseiidae. Persian Journal of Acarology, 2(1): 63-157.

Krantz, G. W. (1978). Amanual of Acarology. Orgenstate University Book Store, Inc. Corvallis, $509 \mathrm{pp}$.

Lindquist, E. E., G. W. Krantz and D. E. Walter (2009). Order Mesostigmata. In: Krantz, G.W. and D. E. Walter (Eds.), A Manual of Acarology, $3^{\text {rd }}$ ed. Texas Tech University Press, pp. 124-232.

Mahgoob, A. E. A., M. E. Tharwat, S. O. Kilany, T. S. Hafez (2006). Mite fauna associated with some domestic and wild agricultural animals and their habitat in Egypt. Arab Universities Journal of Agricultural Science, 14(1): 475-490.

Shereef, G. H., M. A. Zaher and A. M. Afifi (1980). Mites inhabiting organic manures in Egypt. Proc. ${ }^{\text {st }}$. Conf. Prot. Res. Ins., 3: 107-120.

Zaher, M. A. (1986). Survey and ecological studies of phytophagous, predaceous and soil mites in Egypt. Final report PL 480, Programme USA Project No. EG. ARS-30, grant No. FG-139. Faculty of Agriculture, Cairo University.

Zaher, M. A., G. M. Shereef and A. M. Afifi (1980). Population density on mites in three types of organic manures. Proc. 1st Conf. p1. Prot. Res. Ins., III: 97-105. 